НАУКОВИЙ ВІСНИК




entific secturific messenger of Liviv National University of
veterinary Medicine and Biotechnologies

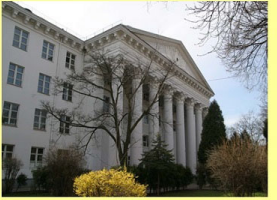

СЕРЯЯ "ЕКОНОМІчН НАУК

Том 22 № 95 2020
Науковий вісник Аьвівського національного університету ветеринарної медицини та біотехнологій імені С.3. Гжицького. Серія: Економічні науки

\author{
Scientific Messenger of Lviv National University \\ of Veterinary Medicine and Biotechnologies. \\ Series: Economical Sciences
}

\title{
Features of agricultural producers economic behavior in Ukraine
}

\section{T. T. Nebozhenko}

Stepan Gzhytskyi National University of Veterinary Medicine and Biotehnologies Lviv, Ukraine

Article info

Received 02.09.2020

Received in revised form 02.10 .2020

Accepted 05.10.2020

Stepan Gzhytskyi National University of Veterinary Medicine and Biotechnologies Lviv,

Pekarska Str., 50, Lviv, 79010, Ukraine.

Tel.: +38-096-695-94-55

E-mail: nebozhenko008@gmail.com
Nebozhenko, T. T. (2020). Features of agricultural producers economic behavior in Ukraine. Scientific Messenger of Lviv National University of Veterinary Medicine and Biotechnologies. Series: Economical Sciences, 22(95), 27-31. doi: 10.32718/nvlvet-e9505

The economic behavior of business structures in agriculture directly depends on the organization of their cooperation in the economic activity process. The aim of the article is to study the features of modern economic behavior of agricultural producers in Ukraine. To do this, the author identified the distribution factors of organizational and legal forms of agricultural production by economic behavior type, as well as organizational and legal features of individual models of economic behavior of agricultural production in Ukraine. Materials of thematic scientific publications, as well as empirical methods (observation and comparison) and theoretical methods (analysis and synthesis, modeling) were used to highlight the features of the object of study. The influence of the oligarchic model of the national economy of Ukraine on the structural transformation of agricultural production entities in the form of subordination of the interests of the state to the interests of individual social groups and the low effectiveness of antitrust legislation is investigated. The author found that in Ukraine the dual structure of agricultural entities was formed, in which two models of their economic behavior were simultaneously developing. The corporate model is represented by large commodity production of agricultural products based on utilization of the resource potential of the reorganized collective agricultural enterprises. Individual small-scale model is presented in agricultural production using the resource potential of private households and farms. The author found out that the organizational and legal forms of agricultural business entities will be determined by their participation in the contract system, the feasibility of cooperation or their integration. Prospects for further research in this area are a comparative analysis of the role of behavioral economy in the economic growth of organizational forms of agricultural producers in Ukraine, as well as assessing the impact of innovative technologies on the evolution of management approaches in the agricultural sector.

Key words: agrarian sector of economy, state regulatory policy, economic behavior, economic interests, organizational and legal form of enterprise, agricultural producer.

\section{Особливості економічної поведінки сільськогосподарських виробників в Україні}

\section{T. Т. Небоженко}

Львівський національний університет ветеринарної медицини та біотехнологій імені С. 3. Гжицького, м. Львів, Україна

Економічна поведінка підприємницьких структур у сільському господарстві безпосередньо залежить від організації їх співпраиі в процесі господарської діяльності. Метою статті виступає дослідження особливостей сучасної економічної поведінки сільськогосподарських виробників в Україні. Для изього автором виявлено фактори розподілу організаційно-правових форм суб'єктів сільськогосподарського виробництва за типом економічної поведінки, а також організаційно-правові особливості окремих моделей економічної поведінки суб'єктів сільськогосподарського виробництва в України. Для виділення особливостей об'єкту дослідження були використані матеріали тематичних наукових публікацій, а також емпіричні методи (спостереження та порівняння) та теоретичні методи (аналіз та синтез, моделювання). 3'ясовано вплив олігархічної моделі національної економіки України на структурні перетворення суб'єктів сільськогосподарського виробництва у вигляді підпорядкування інтересів держсави інтересам 
окремих суспільних груп і низької дієвості антимонопольного законодавства. Виявлено, щзо в Украӥні сформована дуальна структура суб'єктів сільськогосподарського виробництва, у якій одночасно розвиваються дві моделі їх економічної поведінки. Корпоративна модель представлена великим товарним виробництвом сільськогосподарської продукиії на основі використання ресурсного потениіалу реорганізованих колективних сільськогосподарських підприємств. Індивідуальна модель представлена дрібнотоварним виробництвом сільськогосподарської продукиї на основі використання ресурсного потенціалу особистих селянських господарств $i$ фермерських господарств. 3'ясовано, щуо організаційно-правові форми суб'єктів сільськогосподарського підприємництва визначатимуться їх участю в контрактній системі, а також доиільністю кооперації або їх інтеграції. Перспективами подальиих досліджень у даному напрямку є проведення порівняльного аналізу ролі поведінкової економіки в економічному зростанні організаційних форм сільськогосподарських виробників України, а також оцінки впливу інновачійних технологій на еволючію підходів господарювання в аграрному секторі економіки.

Ключові слова: аграрний сектор економіки, державна регуляторна політика, економічна поведінка, економічні інтереси, організаиійно-правова форма підприємства, сільськогосподарський виробник.

\section{Вступ}

Архаїчні, невиправдано затратні та неефективні структурні перетворення суб'єктів господарського виробництва в сільському господарстві України не змогли модернізувати аграрний сектор національної економіки. Ризиками збереження наявної структури суб'єктів господарського виробництва в сільському господарстві $є$ безповоротна втрата аграрним сектором національної економіки конкурентоздатності та загострення соціальних проблем в сільській місцевості. Про необхідність структурних перетворень суб'єктів сільськогосподарського виробництва наголошують теоретики і практики, а також вказують напрями потоків економічних ресурсів загалом та напрями потоків фінансових ресурсів зокрема.

Відповідно до законів ринку інвестиції спрямовуються у сектори національної економіки з порівняно вищим рівнем рентабельності, тоді як сектори національної економіки 3 порівняно нижчим рівнем рентабельності недоотримують необхідний рівень фінансових ресурсів та банкрутують. Проте такий суто ринковий підхід де-факто не зустрічається ніде, оскільки доповнюється державним регулюванням економіки, рівень якого залежить від моделі національної економіки, зрілості ринкового механізму, цілей соціальноекономічного розвитку та національних пріоритетів державної політики. Тому на сучасному етапі розвитку українського сільського господарства, коли система взаємовідносин між сільськогосподарськими виробниками та державою реформується в напрямку децентралізації, існує потреба в формуванні системи життєдіяльності державної регуляторної політики на основі збалансованого розподілу прав та обов'язків не лише між рівнями виконавців економічних інтересів, а й між державою та сільськогосподарськими виробниками у цілому. Проте, окреме сільськогосподарське підприємство, так і аграрний сектор економіки в сукупності, не завжди демонструє раціональну економічну поведінку через фактичну невизначеність потреб у сільськогосподарській продукції та недостовірну оцінку необхідної інформації для прийняття управлінських рішень.

Економічна поведінка підприємницьких структур у сільському господарстві безпосередньо залежить від організації ї співпраці в процесі господарської діяльності. Оскільки питання взаємодії сільськогосподарських підприємств на взаємовигідній основі актуальне, науковці розглядають його з позиції не лише економіки (Tsapenko, 2014; Lemishko, 2016; Derun, 2018;
Hanzhurenko, 2019; Marchenko, 2019; Rudenko, 2019; Diuk, 2020; Nosenko et al., 2020; Protsenko, 2020; Pchelianska, 2020; Suriak, 2020), а й соціології та психології (Zilberman, 2016; Solodukhin \& Shaitanova, 2017; Petinova, 2018). Окрім того, в процесі здійснення державної регуляторної політики у аграрному секторі економіки знання основних причин нераціональної поведінки сільськогосподарських виробників дозволить передбачити та контролювати подібні ситуації, а тому уникати негативних наслідків такої поведінки.

Метою статті виступає дослідження особливостей сучасної економічної поведінки сільськогосподарських виробників в Україні. Для цього необхідно виявити фактори розподілу організаційно-правових форм суб'єктів сільськогосподарського виробництва за типом економічної поведінки, а також виявити організаційно-правові особливості окремих моделей економічної поведінки суб'єктів сільськогосподарського виробництва в України.

\section{Матеріал і методи досліджень}

Для виділення особливостей об'єкту дослідження були використані матеріали тематичних наукових публікацій, а також емпіричні методи (спостереження та порівняння) та теоретичні методи (аналіз та синтез, моделювання).

\section{Результати та їх обговорення}

На структурні перетворення суб'єктів господарського виробництва в сільському господарстві України здійснює вплив олігархічна модель національної економіки, яка характеризується підпорядкуванням інтересів держави інтересам окремих суспільних груп, низькою дієвістю антимонопольного законодавства, високим рівнем корупції, а також неспроможністю ринку у визначенні загальнонаціональних пріоритетів структурних змін суб'єктів господарського виробництва в сільському господарстві України та акумулюванні ресурсів для їх розвитку.

Окрім того, в аграрному секторі економіки України де-факто сформовано дуальну (бімодельну) структуру суб'єктів сільськогосподарського виробництва (рис. 1), у якій одночасно розвиваються дві моделі економічної поведінки виробників сільськогосподарської продукції:

1. Корпоративна (індустріальна) модель, представлена великим товарним виробництвом сільсько- 
господарської продукції на основі використання ресурсного потенціалу реорганізованих колективних сільськогосподарських підприємств. Серед поширених організаційно-правових форм аграрних підприємств стали аграрні холдинги, вертикально інтегровані сільськогосподарські підприємства, а також господарські товариства, які здійснюють виробництво якомога рентабельніших та насамперед експортоорієнтованих видів сільськогосподарської продукції. Для корпора- тивної моделі економічної поведінки виробників сільськогосподарської продукції характерні тенденції до концентрації носіями економічних інтересів виробництва сільськогосподарської продукції, спроб монополізації ринку фінансових ресурсів, каналів збуту сільськогосподарської продукції, засобів державної фінансової підтримки, а також впливу виразників їх економічних інтересів на формування сприятливої загальнодержавної аграрної політики зокрема.



Рис. 1. Фактори розподілу організаційно-правових форм суб'єктів сільськогосподарського виробництва за типом економічної поведінки

Побудовано автором за (Ostashko, 2004; Leshchyk, 2013; Voronzhak, 2016; Lemishko, 2016)

2. Індивідуальна (традиційна) модель, представлена дрібнотоварним виробництвом сільськогосподарської продукції на основі використання ресурсного потенціалу особистих селянських господарств і фермерських господарств. Для індивідуальної моделі економічної поведінки виробників сільськогосподарської продукції характерні тенденції до освоєння каналів збуту сільськогосподарської продукції насамперед через мережу оптових ринків сільськогосподарської продукції, наявні труднощі в отриманні засобів державної фінансової підтримки та залученні зовнішнього позикового капіталу. Особисті селянські господарства та фермерські господарства, виробляючи низькорентабельні та трудомісткі види сільськогосподарської продукції, насамперед забезпечують потреби споживачів на внутрішньому ринку.
Як бачимо з рис. 1, факторів такого розподілу організаційно-правових форм суб'єктів сільськогосподарського виробництва за типом економічної поведінки декілька. Це надмірна концентрація економічних ресурсів у власності та розпорядженні великих сільськогосподарських підприємств та об'єднань підприємств, які ведуть допоміжну, а не основну діяльність у сфері сільського господарства. Це відчуженість суб'єктів сільськогосподарського виробництва до отриманих результатів сільськогосподарської діяльності, незважаючи на те, що стали землевласниками землі та власниками майна колишніх колективних сільськогосподарських підприємств. Це відсутність довіри суб'єктів сільськогосподарського виробництва до держави та виконавців економічних інтересів через турбулентність інституційних засад аграрної політики держави, невизначеність та мінливість пріоритетів у 
розвитку аграрного сектору економіки України. Це також інтроверсія поведінки носіїв економічних інтересів, оскільки більшість суб'єктів сільськогосподарського виробництва прагнуть де-факто лише забезпечити достойне існування підприємця та його родини, незважаючи на декларування в якості мети господарської діяльності - отримання комерційного прибутку та задоволення потреб суспільства тощо (Voronzhak, 2016).

Тому спостерігаємо одночасно корпоративну та індивідуальну моделі економічної поведінки суб'єктів сільськогосподарського виробництва. За розмірами земельного банку лідирують господарські товариства та так звані агрохолдинги. Фермерські господарства через труднощі в отриманні засобів державної фінансової підтримки та залученні зовнішнього позикового капіталу не отримало належного розвитку. У свою чергу, не сприймається кооперація, як партнерська організаційно-правова форма господарювання в аграрному секторі суб'єктами сільськогосподарського виробництва через її асоціації з недоліками колишніх колективних сільськогосподарських підприємств. Все це характеризує ефективність чинного правового забезпечення процесу трансформації сільськогосподарських організаційно-правових форм та рівень його впливу на розвиток аграрного сектору національної економіки та територіальних громад у сільській місцевості України.

Очевидно, що такий напрям трансформації організаційно-правових форм аграрних підприємств, як вдосконалення економічних відносин між ними шляхом кооперації та їх інтеграції, видається доречним. Водночас, можливості кооперації та їх інтеграції суб'єктів сільськогосподарського виробництва як майбутніх великих виробників кінцевої сільськогосподарської продукції будуть визначатися низкою обставин.

По-перше, інтегровані формування суб'єктів сільськогосподарського виробництва будуються на основі вертикальної інтеграції тісно пов'язаних між собою кооперованими зв'язками сільськогосподарських підприємств, продукція яких переважно надходить у вигляді сировини для виробництва та випуску кінцевого продукту аграрного сектору національної економіки. Очевидно, що кількість таких сільськогосподарських підприємств обмежена, тому можливості створення інтегрованих формувань суб'єктів сільськогосподарського виробництва навколо переробних за цим принципом сільськогосподарських підприємств практично вичерпані. Про це свідчить досвід формування аграрних холдингів у структурі суб'єктів сільськогосподарського виробництва України та ефективність їх господарювання на орендованих земельних угіддях площею до 50 тис. га (Isakova, 2015).

По-друге, серед решти суб'єктів сільськогосподарського виробництва самостійними є велика кількість малих і середніх сільськогосподарських підприємств, які виробляють сільськогосподарську продукцію для забезпечення потреб споживачів на внутрішньому ринку. Тому за своїм продуктовим профілем вони представляють відносно самостійні виробництва сільськогосподарської продукції, які ймовірно недоцільно об'єднувати 3 іншими сільськогосподарськими підприємствами чи інтегрованими формуваннями. Окрім того, їх територіальне розташування та відсутність в регіоні діяльності суб'єктів сільськогосподарського виробництва тісно пов'язаних між собою кооперованими зв'язками переробних підприємств можуть перешкоджати трансформації цих самостійних підприємств в інтегровані формування суб'єктів сільськогосподарського виробництва. Водночас, варто також враховувати доцільність виведення зі структури малих і середніх фермерських господарств тих суб'єктів сільськогосподарського виробництва, які ведуть натуральне господарство, за рахунок створення спеціалізованих сільськогосподарських підприємств 3 широкою регіональною та міжгалузевою сферою обслуговування.

По-третє, важливим чинником інтегрованих формувань суб' єктів сільськогосподарського виробництва як єдиних виробничо-господарських комплексів $\epsilon$ можливість концентрації та централізації економічних ресурсів. Досвід великих аграрних холдингів доводить, що в більшості великих інтегрованих формувань на основі наявних технічних, технологічних і переробних підрозділів вдалося створити потужні виробничі, обслуговуючі та переробні центри, в яких здійснюється цикл, що включає виробництво та переробку сільськогосподарської сировини, зберігання та реалізацію готової сільськогосподарської продукції. Такі процеси кооперації та інтеграції відбувалися насамперед на великих, переробних підприємствах, навколо яких i створювалися інтегровані формування суб'єктів сільськогосподарського виробництва, оскільки на середніх і невеликих переробних підприємствах не було можливості таких трансформацій.

\section{Висновки}

3 огляду на особливості дуальної структури економічної поведінки суб'єктів сільськогосподарського виробництва в Україні, очевидно, що перспективними основними сільськогосподарськими організаційноправовими формами в аграрному секторі економіки можуть стати об'єднання малих і середніх суб'єктів сільськогосподарського виробництва. Водночас, залишаться малі та середні сільськогосподарські підприємства, як основні та первинні осередки організаційно-правових форм аграрного сектора економіки, відносно відособлені в виробничо-технологічному, територіальному і організаційному аспектах. Проте, незалежно від того, увійдуть ці сільськогосподарські підприємства до складу інтегрованих формувань суб'єктів сільськогосподарського виробництва або збережуться як самостійні господарські одиниці, їх виробнича структура і профіль повинні відповідати вимогам ефективної спеціалізації у сфері сільського господарства (Nurmuhametov, 2015). В цілому, організаційно-правові форми суб'єктів малого і середнього сільськогосподарського підприємництва будуть визначатися їх участю в контрактній системі, доцільністю кооперації або їх вертикальної, горизонтальної інтеграції з урахуванням можливостей централізації і концентрації наявних економічних ресурсів. 
Перспективи подальших досліджень. Перспективами подальших досліджень у даному напрямку є проведення порівняльного аналізу ролі поведінкової економіки в економічному зростанні організаційних форм сільськогосподарських виробників України. Окрім того, перспективним напрямком дослідження може стати оцінка впливу інноваційних технологій на еволюцію підходів господарювання в аграрному секторі економіки.

\section{References}

Derun, A. M. (2018). Ratsionalizatsiia orhanizatsiinykh form hospodariuvannia $\mathrm{v}$ natsionalnii ekonomitsi: dys. ... kand. ekon. Nauk. IPK DSZU. K. (in Ukrainian).

Diuk, A. A. (2020). Ekonomichna otsinka formuvannia sotsialnoi vidpovidalnosti v silskohospodarskomu pidpryiemnytstvi. Visnyk ahrarnoi nauky Prychornomoria, 2, 47-53. doi: 10.31521/2313092X/2020-2(106)-5 (in Ukrainian).

Diuk, A. A. (2020). Orhanizatsiino-ekonomichna sotsializatsiia pidpryiemnytstva na seli $\mathrm{v}$ umovakh transformatsii hospodariuvannia. Ekonomika APK, 5, 108-117. doi: 10.32317/2221-1055.202005108 (in Ukrainian).

Hanzhurenko, I. V. (2019). Adaptyvnist marketynhovolohistychnykh system subiektiv ahrarnoho biznesu. Aktualni problemy innovatsiinoi ekonomiky, 3, 3846. doi: 10.36887/2524-0455-2019-3-6 (in Ukrainian).

Isakova, D. (2015). Reitynh 20 naiefektyvnishykh ahrokompanii Ukrainy. Forbes Ukraina. URL: http://forbes.net.ua/ua/magazine/forbes/1399408-

rejting-20-najefektivnishih-agrokompanij-ukrayini (in Ukrainian).

Lemishko, O. O. (2016). Rehuliuiuchyi vplyv podatkovoho navantazhennia na ekonomichni protsesy u silskomu hospodarstvi. Molodyi vchenyi, 9(36), 54-60. URL: http://molodyvcheny.in.ua/files/journal/2016/9/55.pdf (in Ukrainian).

Leshchyk, I. B., \& Pyrih, H. I. (2013). Orhanizatsiinoekonomichni transformatsii $\mathrm{v}$ ahrarnomu sektori ekonomiky. Stalyi rozvytok ekonomiky, 3, 327-331 (in Ukrainian).

Marchenko, V. M. (2019). Praktychnyi dosvid realizatsii konkurentnykh stratehii pidpryiemstv. Pidpryiemnytstvo ta innovatsii, 7, 65-68. doi: 10.37320/2415-3583/7.10 (in Ukrainian).

Nosenko, Yu. M., Nechyporenko, O. M., \& Sinelnyk, L. M. (2020). Innovatsiini ahroklastery yak forma intehratsii naukovo-osvitnoi diialnosti ta biznesu. Ekonomika APK, 5, 77-86. doi: 10.32317/22211055.202005077 (in Ukrainian).
Nurmuhametov, I. M. (2015). Prioritetnye napravlenija sovershenstvovanija razvitija malogo i srednego predprinimatel'stva $\mathrm{v}$ agrarnom sektore jekonomiki. Vestnik Marijskogo gosudarstvennogo universiteta, 1, 66-69 (in Ukrainian).

Ostashko, T. O. (2004). Instytutsionalno-strukturni transformatsii ahrarnoho sektora: monitorynh, otsinka, rehuliuvannia: avtoref. ... d-ra ekon. Nauk. IEP NANU. K. (in Ukrainian).

Pchelianska, H. O. (2020). Povedinka spozhyvachiv na prodovolchomu rynku: instytutsiinyi ta marketynhovyi pidkhody. Ekonomika APK, 3, 47-56. doi: 10.32317/2221-1055.202003047 (in Ukrainian).

Petinova, O. B. (2018). Ekonomichna povedinka: do pytannia eksplikatsii poniattia. Hrani, 21(2), 60-65. doi: 10.15421/171817 (in Ukrainian).

Protsenko, V. M. (2020). Metodolohichni aspekty intensyfikatsii upravlinnia ekonomichnoiu povedinkoiu pidpryiemstv $\mathrm{v}$ umovakh neoindustrialnoi modernizatsii. Problemy ekonomiky, 1(43), 166-172. doi: 10.32983/2222-0712-2020-1166-172 (in Ukrainian).

Rudenko, M. V. (2019). Vplyv tsyfrovykh tekhnolohii na ahrarne vyrobnytstvo: metodychnyi aspekt. Ekonomika ta upravlinnia natsionalnym hospodarstvom, 30(69), 30-37. doi: 10.32838/25234803/69-6-28 (in Ukrainian).

Solodukhin, S. V., \& Shaitanova, Ye. S. (2017). Suchasni pidkhody do analizu vplyvu povedinkovykh faktoriv $\mathrm{v}$ upravlinni ekonomichnymy obiektamy. Naukovyi visnyk Uzhhorodskoho natsionalnoho universytetu, 15(2), 129-132 (in Ukrainian).

Suriak, A. V. (2020). Innovatsiine spozhyvannia yak suchasna ekonomichna povedinka spozhyvacha. Ekonomichnyi chasopys Skhidnoievropeiskoho natsionalnoho universytetu imeni Lesi Ukrainky, 1, 137-145. doi: 10.29038/2411-4014-2020-01-137-145 (in Ukrainian).

Tsapenko, V. Iu. (2014). Ekonomichna povedinka pidpryiemstv yak osnova dlia pryiniattia upravlinskykh rishen. BIZNESINFORM, 11, 313-315 (in Ukrainian).

Voronzhak, P. V., \& Cheran, Ye. M. (2016). Analiz instytutsionalnykh transformatsii $\mathrm{V}$ ahrarnomu biznesi Ukrainy. Ukrainskyi zhurnal prykladnoi ekonomiky, 1(5), 17-24 (in Ukrainian).

Zilberman, D. (2016). Povedinkova ekonomika, abo Chomu fermery boiatsia ryzykuvaty. AgroPortal.ua. URL: http://agroportal.ua/ua/views/blogs/povedencheskayaekonomika-ili-pochemu-fermery-boyatsya-riskovat (in Ukrainian). 